\title{
Hoax di Media Sosial Facebook: Antara Edukasi dan Propaganda Kepentingan
}

\author{
Muhamad Tisna Nugraha \\ Institut Agama Islam Negeri Pontianak - Indonesia
}

\begin{abstract}
Technological advances have encouraged the raise of a variety of social media services features which are more and more innovative, interesting, and variative. This technological development impacting in human civilization, especially pertaining to multidimensional as well as multilateral interaction. The benefit of social media was accompanied by the negative side, such as slander, conflict, nation- disintegration, and separatism. This is a qualitative research applying case- study approach. The instruments used in this research are documentation, observation, and library research. The conclusion is that education has an important role in using social media. Otherwise, social media will only be used as the media for commiting crime, including disseminating tendentious words, hoax, and propaganda.
\end{abstract}

Kemajuan teknologi telah mendorong munculnya berbagai fitur layanan media sosial yang semakin inovatif, menarik, dan variatif. Perkembangan teknologi ini berdampak pada peradaban manusia, terutama yang berkaitan dengan interaksi multidimensional maupun multilateral. Manfaat media sosial disertai oleh sisi negatif, seperti fitnah, konflik, disintegrasi bangsa, dan separatisme. Ini adalah penelitian kualitatif yang menerapkan pendekatan studi kasus. Instrumen yang digunakan dalam penelitian ini adalah dokumentasi, observasi, dan penelitian kepustakaan. Kesimpulannya adalah bahwa pendidikan memiliki peran penting dalam menggunakan media sosial. Jika tidak, media sosial hanya akan digunakan sebagai media untuk melakukan kejahatan, termasuk menyebarkan kata-kata tendensius, tipuan, dan propaganda.

Keywords: hoax; social media; education; propaganda

Korespondensi Penulis: Muhamad Tisna Nugraha (tisnanugraha2014@yahoo.com). Instutut Agama Islam Negeri Pontianak Jl. Letjend. Suprapto No. 19 Pontianak, Indonesia 78122. 


\section{Pendahuluan}

Media sosial dalam satu dekade terakhir ini telah menjadi suatu organisasi besar yang menampung sekumpulan manusia yang berasal dari berbagai wilayah menjadi satu di dalam dunia maya. Anggota dari organisasi ini hidup dan berinteraksi secara online layaknya penduduk dalam suatu negara, meskipun sebenarnya ada diantara mereka tidak mengenal satu sama lain apalagi memilki ikatan emosional di kehidupan nyata.

Perkembangan teknologi di era milineal ini pada kenyataannya telah melahirkan ragam kekuatan publik melalui layanan media sosial, seperti diantaranya facebook, youtube, twitter, instagram, blogspot, wordpress, friendster, dan lain-lain. Dari media sosial ini pula, setiap orang dimungkinkan untuk melakukan interaksi, berbagi informasi, dan menjalin silahturahmi antara satu dengan yang lain meskipun berada di tempat yang berjauhan. Melalui media sosial ini pula hubungan yang lebih multidimensional dan multilateral dimungkinkan untuk terbentuk.

Berdasarkan data dari Global Web Index di tahun 2016 dari 7.39 miliar manusia 31\% diantaranya atau sekitar 2.31 miliar orang di muka bumi, tercatat adalah pengguna aktif media sosial. Dalam soal lama waktu penggunaan, Indonesia ternyata menduduki peringkat 9 yang rata-rata warganet (netizen)-nya menghabiskan waktu sebanyak 2,9 jam/perhari. Sedangkan negara yang penduduknya paling lama menghabiskan waktunya di media sosial adalah Filipina dengan rata-rata lama pengguna sebanyak 3,7 jam/perhari. Untuk jenis layanan media sosial yang paling banyak dipilih warganet pada tahun 2016, facebook menempati posisi pertama dengan jumlah pengguna sebanyak 1,59 miliyar pengguna. Jumlah tersebut mengalahkan jumlah penduduk Indonesia yang hanya mencapai angka 200 jutaan. Adapun urutan pertama terbanyak pengguna facebooknya adalah Amerika Serikat dengan jumlah pengguna sebanyak 194 juta orang. Sedangkan Indonesia berada diposisi ke empat dengan jumlah pengguna sebanyak 82 juta orang.

Selanjutnya berdasarkan data tahun 2019 sebagaimana dikutip dari Pertiwi (2019) diperoleh informasi bahwa dari sekitar150 juta pengguna media sosial di Indonesia, facebook menjadi aplikasi media sosial yang paling banyak digunakan dengan penetrasi sebesar 81 $\%$. Jumlah tersebut disusul oleh aplikasi media sosial seperti instagram dan twitter.

Pemilihan facebook sebagai apalikasi online media sosial dengan pengguna terbanyak bukan-lah tanpa alasan. Facebook menawarkan fitur-fitur yang disukai dan mudah untuk dioperasionalkan, seperti fitur untuk memilih pertemanan, membuat grup, mengirim pesan, mengirm berkas office, serta berbagi, video dan gambar.

Kedahsyatan dari jejaring sosial seperti facebook terbilang cukup fenomenal dalam waktu relatif singkat, berbagai peristiwa, cerita dan berita dapat dengan mudah menyebar secara viral di tengah warganet. Ada yang sekedar menjadi pelajaran (ibrah) dan ada pula yang kemudian mersepon dalam bentuk tindakan, sehingga tidak jarang diantara individu atau 
kelompok saling bertikai dangan dasar 'prasangka buta'. Dengan demikian dapat digaris bawahi, teknologi media sosial ada diantaranya digunakan untuk berbagai hal positif seperti menjalin silahturahmi (persahabatan), berdagang, dan berbagai informasi. Namun tidak sedikit juga yang secara sengaja, sistematis, teroganisisir dan sporadis melakukan berbagai aksi-aksi kriminal dengan istilah cybercrime, seperti melakukan pencemaran nama baik, penyebaran konten pornografi, penipuan, penghinaan, spam, spyware, dan masih banyak lagi.

Di Indonesia, selain beberapa kasus di atas negara ini juga sedang dihadapkan dengan 'krisis berita' berupa penyebaran berita hoax yang merambah secara masif dan terstruktur dari level sosial atas hingga level sosial bawah, dari kota hingga ke desa, dan bahkan dari kalangan tua hingga ke kalangan muda. Banyaknya ragam pengguna media sosial dari segi latar belakang agama, pendidikan, jenis kelamin, pekerjaan, suku bangsa dan lain-lain tidak jarang menimbulkan reaksi beragam terhadap suatu permasalahan bahkan diantanya menyulut permusuhan dan konflik di antara berbagai golongan.

Dari penjelasan di atas, tampaknya jelas bahwa hoax tidak kalah berbahayanya dengan permasalahan narkotika, pornografi dan tindak kriminal lainnya yang jika dibiarkan dapat meresahkan dan membahayakan kehidupan sosial masyarakat. Di sisi yang berbeda hoax juga dimungkinkan untuk dapat digunakan oleh sebuah institusi yang syah seperti pemerintah dalam rangka membentuk opini positif terhadap orang, institusi dan kebijakan tertentu sebagai bentuk propaganda guna mewujudkan tujuan tertentu.

Hoax tidak hanya sebuah permasalahan sosial semata, melainkan juga pembelajaran bagi setiap orang untuk dapat lebih berfikir jernih dalam bersikap, berhati-hati dalam berbuat, teliti dalam menerima informasi, serta mewujudkan masyarakat yang belajar untuk dapat hidup bersama (learning lives together) dengan mengedepankan kemaslahatan dan aturan yang berlaku. Disini karakter seseorang akan terbentuk secara perlahan agara dapat menjadi lebih baik dan berpangalaman dalam sikap, ucapan maupun tindakan.

Tulisan ini berangkat dari penelitian kualitatif deskriptif dengan pendekatan studi kasus (case study). Penelitian kualitatif deskriptif dimaksudkan, untuk memperoleh informasi yang dipaparkan secara apa adanya terhadap suatu kondisi objek secara ilmiah. Sedangkan pendekatan studi kasus merupakan sebuah penelitian yang berupaya menyelidiki suatu fenomna atau gejala-gejala yang tampak dalam masyarakat maupun kehidupan nyata. Hal ini sebagaimana pula diungkapkan oleh Daymon \& Holloway (2008) bahwa lazimnya dihubungkan dengan penyelidikan intensif terhadap sebuah lokasi, organisasi, atau kampanye. Selain itu, Umar (2003) menyatakan bahwa metode studi kasus menghendaki suatu kajian yang rinci, mendalam, menyeluruh atas objek tertentu yang biasanya relatif kecil selama kurun waktu tertentu, termasuk lingkungannya.

Selanjutnya, berkaitan dengan hasil perolehan data dalam penelitian, hal ini diperoleh setelah peneliti melakukan pengolahan data dan 
analisa data yang berasal dari sumber data primer berupa berita-berita yang diperoleh di media elektronik dan sumber data skunder yang diperoleh dari pengamatan langsung peneliti terhadap media sosial. Untuk itu, instrumen yang digunakan dalam penelitian ini berupa dokumentasi, observasi dan kajian kepustakaan (library research).

\section{Hoax dan Propaganda Kepentingan di Media Sosial Facebook}

\section{Hoax dan Media Sosial Facebook}

Hoax adalah istilah untuk berita palsu yang tidak ada kebenarannya. Hoax dapat menimbulkan keresahan, paranoid dan ketakutan pada objek-objek tertentu walaupun hal ini terkadang tidak menimbulkan kerugian material secara langsung. Khozin (2018) menyebutkan bahwa hoax adalah informasi menyimpang dari fakta yang sebenranya dan harus ditelusuri kembali dengan menggunakan pikiran sehat. Sejalan dengan pendapat tersebut Musfah (2018) menyatakan bahwa adalah berita bohong dengan tujuan mendeskriditkan individu atau kelompok tertentu. Kehadiranya tidak dapat dipertanggungjwabkan dan perlu diadakan penelusruan serta pemeriksaan lebih lanjut.

Hoax di media sosial dibuat begitu akurat dan logis namun sebenarnya hanyalah kabar bohong dan 'isapan jempol' belaka. Biasanya hoax menyebar dengan cepat dari milis ke milis, dari satu forum ke forum yang lain, dari group satu ke grup lainnya dan jelas bisa menyebar melalui Plurk. Pesan hoax yang ada saat ini dapat dikelompokan dalam tiga bagian. Pertama, berita hoax kejutan (shock news). Yaitu suatu berita yang terkesn bombastis, fenomenal, heboh, penting dan seakan-akan perlu untuk diketahui oleh orang banyak. Padahal jika diusut berita tersebut sebenarnya tidaklah demikian adanya. Bilapun berita tersebut adalah berita yang penting, si penerima berita belum tentu merasa perlu dengan berita tersebut umumnya syok news ditampilkan dengan gambar menarik dan narasi yang hiperbola. Misalnya pelaku hoax menampilkan suatu gambar religius, indah atau menarik. Disitu ia akan berkata; 'ketik' amin' jika anda ingin memiliki/pergi ke tempat tersebut". Kedua, hoax sarkasme. Hoax jenis ini adalah hoax yang bersifat monohok, menyidir, dan agresif untuk menjatuhkan lawan. Hoax dilihat dari pelakunya terbagi ke dalam dua, yaitu warganet yang terang-ternagan bersifat "face to face" tetapi banyak juga diantaranya memilih model yang kedua, yaitu menggunakan sejumlah akun bodong (palsu) dan anonim. Ketiga, berita hoax boomerang. Hoax model ini adalah berita yang dibuat seolah-olah menjelekan orang atau kelompok tertentu padahal berita yang dibuatnya tidak tidaklah benar adanya. Dengan berita hoax model seperti ini diharapkan meningkatkan prastise dan kepercayaan publik pada orang yang seola-olah dibuat dizalimi.

Subtansi berita hoax, sebenarnya tidak semua atau selalu berisi konten-konten yang monohok, agresif serta menyerang individu atau organisasi tertentu, melainkan malah berisi halhal baik seperti nasehat, peringatan dan hikmah dari suau peristiwa. Hoax model ini biasanya mengarahkan pada pembaca untuk memiliki motivasi dalam beribadah, berhati-hati dalam memilih produk, mengajak untuk mau mendermakan hartanya di jalan Tuhan, dan lain 
sebagainya. Namun apapun alasannya, berita seperti itu tetap saja itu adalah hoax atau berita palsu yang tidak dapat dipertanggungjawabkan.

Selanjutnya adapun beberapa ciri-ciri berita hoax antara lain 1) Berita tentang hoax yang disebarkan pelaku, biasanya adalah anjuran kepada para pembacanya untuk meneruskan berita tersebut kepada orang lain. Hal ini melibatkan sisi psikologi manusia. Karena sifat manusia mempunyai keinginann untuk sharing atau berbagi, terlebih lagi bila mempunyai informasi penting yang perlu diketahui oleh masyarakat luas. Selain itu, penyebaran berita hoax yang kemudian viral ini juga tidak luput dari dukungan mudahnya menyebarkan pesan yang sama dengan hanya sekali menekan send atau forward. 2) Sumber yang tidak jelas. Hoax pada awalnya berasal dari "akun bodong" atau akun palsu yang tidak dapat dipertanggungjawabkan kebenarannya. Akun ini juga biasanya membagikan berita hoax dengan mengajak warganet membuka/merujuk pada sumber website persekutuan hoax atau situs yang tidak kredible, web hosting yang terbilang murah untuk sebuah media informasi besar berbagi berita dan fakta, web-nya mudah dan tidak kompleks pembuatannya, serta kadang memiliki kesamaan nama dengan website resmi namun ada penambahan huruf atau angka di depan atau belakang alamat surel website tersebut dibanding aslinya.

Keberadaan berita hoax tidaklah patut dibiarkan berkembang di masyarakat, karena hoax cenderung membawa pada kebohongan, keresahan, dan rawan pertikaian. Musfah (2018) menyebutkan ada beberapa bahaya yang dapat ditimbulkan dari hoax. Pertama, hoax menimbulkan konflik horizontal. Hal ini berpengaruh pada iklim interaksi sosial masyarakat yang bersifat hetrogen dan multikultural menuju pada disintergrasi dan permusuhan. Kedua, hoax dapat menimbulkan konflik vertikal, yaitu konflik antara masyarakat dengan pemerintah atau dari kelompok bawah ke kelompok atas. Hal ini karena hoax kerap kali berisi ujaran kebencian terhadap individu, kelompok atau partai tertentu, yang pada akhirnya melahirkan mosi ketidak percayaan pada penguasa dan disintergrasi nasional.

Penelitian Eye Trac yang dilakukan oleh Poynter Institute of Media Studies di St. Petersbug, Florida (AS) mengungkapkan bahwa ketika seseorang membaca berita yang pertama kali dilihatnya adalah gambar bewarna dalam berita tersebut, dilanjutkan kemudian dengan membaca judul berita, caption (keterangan foto), briefs (tulisan pendek) dan garis grafis lainnya. Hoax dapat menjadi viral dengan mudah dalam masyarakat yang reaksioner, mudah terpancing, tidak teliti dan kurang melek literasi. Terkadang ada sebagian masyarakat yang terlalu berlebihan menanggapi suatu isu sehingga membangun suatu opini tanpa peninjauan kembali (tabayyun) yang rawan memicu ketegangan, perkelahian bahkan kematian sejumlah orang yang tak bersalah.

Persoalan lain mengenai fenomena hoax adalah lahirnya sejumlah warganet yang mudah terperdaya dengan berita instan Biasanya berita ini disajikan oleh sebuah provider yang menyedikan layanan luas dengan hastag yang mudah dicari semsial twitter dan instagram, 
termasuk oleh group sharing informasi semisal facebook dan whatsapp. Di sini ada saja orang yang secara sukarela berbagi informasi gratis ter-update dengan orang lain, tanpa melalui proses verifikasi. Di satu sisi sukarelawan ini mendapat kepuasan dari banyaknya like (acungan jempol), komentar dan take give beritanya di share kembali, forward atau retweet. Disisi lain, penerima berita yang tidak melek lietartur dan informasi merasa diuntungkan karena menganggap dirinya dapat tahu lebih dulu berita terkini dibandingkan dengan orang lain.

Adapun yang dimaksud dengan media sosial (social media), menurut Firda dan Faiza (2018) adalah sebuah sarana interaksi sosial berbasis daring (dalam jaringan) yang terhubung dengan internet, yang berfungsi memudahkan penggunanya untuk saling berbagi informasi atau cerita, berpartisipasi, melakukan komunikasi lewat berkirim pesan, menjalin relasi dan membuat sebuah jaringan. Nugraha (2018), menyatakan:

"Melalui media sosial, waktu, jarak dan tempat tidak lagi menjadi kendala bagi setiap orang maupun kelompok dalam berinteraksi. Selain itu, dengan kemajuan teknologi ini, paradigma pemikiran terhadap berbagai persoalan yang ada di dunia, tidak lagi dipandang berdasarkan tema maupun studi kawasannya. Disini, pembicaraan permasalahan, heterogenitas sosial, ras, agama dan sosial kehidupan di sekitar wilayahnya adalah suatu yang telah usang. Lebih jauh, mereka sudah berdialog tentang apa yang saat ini sedang viral, trend, hastag dan booming. Meskipun itu bisa saja berada di belahan dunia yang lain."

Berdasarkan pendapat di atas, media sosial telah menjadi tempat atau wadah bersosialisasi, berekspresi sekaligus wahana untuk mengembangkan kepribadian di dunia maya. Melalui media sosial seseorang jugadapat belajar banyak hal seperti bagaimana melakukan pemanfaatan teknologi tepat guna, sains dan ilmu pengetahuan, serta berbagi informasi terkait perkembangan trend yang bersifat kekinian.

Media sosial sebagaimana fungsi utamanya juga bermanfaat untuk melakukan interaksi sosial, seperti mengobrol, bertukar pikiran, berdiskusi, termasuk sebagai tempat untuk mencurahkan perasaan. Melalui berbagai fitur yang terdapat di media sosial, hal ini tentu saja memungkinkan adanya interaksi global dimana masyarakat dalam yang memiliki koneksi serta fitur layanan tersebut akan mengetahui kebiasaan orang lain dari komentar, berita, cerita atau peristiwa yang di upload-nya ke publik meskipun mereka berada di belahan dunia yang lain.

Media sosial saat ini tanpa disadari telah berevolusi menjadi apa yang disebut dengan "institusi sosial manusia di dunia maya". Intitusi ini lahir dari berbagai interkasi sosial sebagai bentuk dorongan persahabatan di dunia maya antar sesama warganet yang kemudian membentuk kebiasaan tertentu, kelompok atau group, dan menciptakan seperangkat nilai-nilai sosial untuk disepakati. Interaksi sosial di dunia maya juga hampir tak jauh berbeda dengan dunia nyata. Ada nilai-nilai yang harus dijunjung dan ditaati tentang mana yang baik dan mana buruk. Mana perbuatan yang harus dilakukan dan perbuatan mana yang harus dihindari. Bagi warganet yang melanggar kesepakatan ini akan dicap negatif, dijauhi, disisihkan, dihapus dari daftar teman atau member dalam sebuah grup. Tidak mengherankan jika Atmadjati (2018) 
berpendapat bahwa media sosial populer atau yang sedang digandrungi di dunia maya memiliki pengaruh yang besar dalam penyebaran berita, peristiwa dan informasi.

Selanjutnya, sebagai media sosial dengan pengguna terbanyak di Indonesia. Facebook adalah layanan media sosial yang juga tidak dapat dilepaskan dari bahaya perilaku hoax yang dilakukan oleh para pengguna yang tidak bertanggungjawab. Hoax dalam bentuk masif biasanya disebarkan semata-mata untuk mendapatkan keuntungan ataupun target tertentu. Sebut saja kasus yang telah diungkap Kepolisan dan sempat viral di tahun 2018, berkaitan dengan hoax yang disebarkan oleh suatu komunitas atau organisasi terstruktur yang menamakan dirinya sebagai MCA dan Saracen Grup.

Aktivitas penyebaran hoax yang teroganisir tersebut akan semakin meningkat menjelang politik pemilihan umum dan pemilihan daerah. Kelompok penyebar hoax yang dapat disebut pula dengan istilah Buzzer Hoaks berdasarkan dokumentsi yang diperoleh di halaman Sugiharto (2016) berhasil meraup keuntungan hingga ratusan juta rupiah dari setiap operasi yang dilakukannya. Artinya, hoax yang berkembang memang bukan semata-mata disebabkan oleh faktor kelalaian dari pemilik akun media sosial, melainkan juga sebuah propaganda kepentingan yang teroganisir dan memiliki tarif bayaran tertentu.

Kejahatan hoax tidak tertutup kemungkinan juga dilakukan oleh kedua belah pihak yang saling bersebrangan dalam memperebutkan suara di pemilihan raya. Namun belum tentu juga tokoh utama yang berseteru merupakan pelaku penyebaran hoax. Para simpatisan, tim sukses, pendukung, atau orang yang memiliki kebencian maupun dendam lama dengan lawan politiknya bisa saja menghalalkan berbagai cara termasuk melakukan penyebaran hoax untuk mencapai tujuan yang diinginkan.

\section{Hoax dan Propaganda Kepentingan}

Media sosial ibarat koin bermata dua, disatu sisi memiliki dampak yang positif namun disisi lain banyak kejahatan yang sebenarnya justru terjadi dari salah pemanfaatan media sosial tersebut. Prostitusi online, penjualan narkoba dan senjata, serta perundungan (bullying) adalah beberapa kejahatan yang kerap muncul sebagai bentuk penyalahgunaan media sosial. Bahkan tidak jarang kejahatan ini sampai melibatkan campur tangan sebuah negara dalam rangka melakukan kegiatan mata-mata.

Jumlah pengguna media sosial dengan angka yang fantastis menjadikan media ini kerap kali dimanfaatkan oleh suatu kelompok, golongan tertentu. Bahkan tidak tertutup kemungkinan oleh pemerintah yang syah dalam rangka menggiring opini publik atau sekedar mengalihkan isu demi mencapai tujuannya. Hal inilah yang kemudian dimaksud dengan tujuan propaganda yang diantaranya berguna untuk membangun reputasi ataupun menjatuhkan lawan politiknya. Dalam tulisan Qadaruddin (2016) menyebutkan bahwa propaganda merupakan suatu upaya yang disengaja dan sistematis dalam membentuk persepsi, memanipulasi alam pikiran atau kognisi dan mempengaruhi secara langsung perilaku seseorang atau kelompok agar dapat memberikan respon sesuai apa yang dikehendaki pelaku propaganda. Selanjutnya 
Bungin (2018) menambahkan bahwa dalam praktiknya propaganda ini berkaitan denga suatu kebaikan, jasa dan nilai-nilai yang diperjuangkan, menyembunyikan keburukan dan kelemahasn serta membuat subjek propaganda menjadi pahalwan.

Dari dua penjelasan tersebut di atas, propaganda sebenarnya tidak lagi hanya dilakukan oleh kelompok anti-pemerintah, gerakan sparatis, lawan politik dan aliran-alairan radikal. Propaganda dalam arti luas juga telah melibatkan unsur pemerintah sendiri sebagai pengguna jasa propaganda yang menggunakan isntrumen ini sebagai alat kontrol sosial, pencitraan dan kaderisasi pemikiran atau ideologi politik penguasa. Praktik propaganda ini secara terang dapat dilihat pada saat pendudukan Jepang di Indonesia, dimana jepang menggunakan semboyan "Tiga A" yang menggambarkan bahwa Jepang adalah pemimpin, pelindung dan cahaya Asia dalam upaya memperoleh simpati masyarakat Indonesia dan mengalihkan isu praktik imperialisme Jepang.

Affandi (2017) menyebutkan bahwa isi pesan propaganda dibagi menjadi dua jenis, yaitu propaganda terbuka dan propaganda tertutup. Sedangkan berdasarkan kealamiahan dan sumbernya, maka propaganda dapat dibagi ke dalam tiga jenis yaitu: White Propaganda, grey Propaganda dan black propaganda. 1) White propaganda biasanya datang dari sumber yang dikenalai atau suatu sumber resmi yang ditandai dengan metode ajakan, bujukan atau seperti standar teknik public relation dan presentasi berat sebelah dari suatu argumentasi. 2) Grey propaganda, biasanya datang dari kelompok abu-abu yang seolah-olah berada pada posisi netral namun tujuannya justru menggiring opini publik secara persuasif ke arah yang diharapkan, dan 3) Black propaganda, yaitu propaganda hitam yang berasal dari sumber yang memang tidak bersahabat (lawan), namun keberadaanya terkamuflase sehingga sulit untuk diungkap apa lagi ditangkap.

Pada media sosial facebook, akun penyebar hoax biasanya merupakan akun siluman. Akun ini dapat di identifikasi dari tidak adanya foto hastag yang bersifat kontinyu maupun komprehensif dengan daftar pertemanan yang ada di facebook-nya. Akun ini juga seringkali tampil dengan logo atau simbol tertentu atau juga gambar yang bersifat non-realisme, sehingga dapat dikatakan mereka tidak pernah menggunakan foto asli. Namun, akun siluman ini juga ada diantaranya tidak sungkan untuk menggunakan foto orang lain yang tidak jelas sumbernya untuk digunakan sebagai profil facebook. Biasanya foto tersebut tidak pernah update, karena foto tersebut bukan merupakan foto dirinya sendiri. Selain itu akun siluman biasanya aktif dalam group facebook atau akun facebook berita yang banyak dihuni atau diukuti member facebook. Itulah alasan kenapa akun siluman jarang mengupdate status namun terlihat aktif dai group atau di facebook berita yang memiliki banyak pengikut.

Berbeda dengan priode sebelumnya alat penyebaran hoax dan propaganda konvensional seperti program televisi, koran, radio dan selebaran-selebaran berita sudah perlahan ditinggalkan karena dinilai kurang efetif, usang dan boros pembiayaan. Banyak orang sudah 
beralih ke media sosial karena instrument ini dianggap solusi yang lebih ampuh dari media konvensional. Media sosial dipilih bukan tanpa alasan, pertimbangan biaya yang lebih murah dan pemanfaatnya yang lebih praktis menjadi salah satu dasar pemilihan media sosial sebagai alat propaganda. Disisi lain, media sosial terbilang sulit untuk dikendalikan apa lagi tidak ada sertifikasi dari pihak berwajib tentang uji kelayakan mengenai siapa yang boleh atau tidak boleh menjadi pengguna media sosial. Hanya bermodal smart phone dan kuota internet seseorang kemudian dapat beraktivitas di dunia maya. Ini tentunya jauh berbeda dengan media konvensional yang berbadan hukum, memiliki penangungjawab, ada proses editing dan tim seleksi tentang kelayakan publikasi. Informasi yang dibagi (share) dalam media sosial sering kali mengarah kepada informasi yang tidak kredibel, karena proses pemberitaanya pun tidak adanya proses verifikasi, berdasarkan "kabar burung". Sayang, pengawasan pihak berwajib terbilang cukup terbatas terhadap penyalahgunaan media sosial. Selain karena minimnya Sumber Daya Manusia (SDM) dan teknologi, biasanya tindakan atau sanksi hukum baru dapat diberikan kepada akun media sosial yang telah melakukan tindakan kriminal seperti pencemaran nama baik, menyebarkan gambar/ video porno, dan berita hoax yang meresahkan berdasarkan laporan korban atau apa yang disebarkan/dilakukanya sudah terlanjur viral dan dianggap meresahkan.

\section{Hoax antara Propaganda dan Edukasi}

Berita hoax telah menjadi salah satu startegi yang dianggap dapat mendatangkan keutungan bagi pihak tertentu dan merugikan di pihak yang lainnya. Lahirnya kesalahpahaman sebagai dampak penyebaran berita hoax dalam skala yang besar bisa saja menyebabkan terjadinya perang dan pembunuhan termasuk memungkinkan sesesorang atau golongan tertentu menang dalam suatu kompetisi politik ataupun suatu pertempuran. Disini perlulah untuk disadari tentang konsep pendidikan 'belajar sepanjang hayat' atau lifelong education sebagai kunci keberhasilan menuju masyrakat milineal yang bermartabat.

Kehadiran hoax di masyarakat sebenarnya menjadi suatu pembelajaran yang amat penting. Dimana peristiwa yang ada di depan mata dapat dianggap sebagai suatu pengalaman berharga untuk menghadapi fase kehidupan yang lebih baik, ibarat pepatah "pengalaman adalah guru yang terbaik". Oleh karena itu Rakhmat (2017) menyebutkan bahwa walaupun masing-masing tingkatan usia berbeda-beda menanggapi suatu peristiwa, namun kedewasaan berpikir tetap menjadi ukuran utama dalam keberhasilan proses pendidikan yang melibatkan pemecahan masalah terkait seperti halnya hoax.

Belajar tidak hanya sekedar untuk tahu, melainkan juga menekankan pentingnya prinsip learning by doing melalui praktik yang sesungguhnya. Karena pada dasarnya belajar dan bekerja merupakan satu kesatuan yang sulit untuk dipisahkan, sebagaimana peserta didik dengan masyarakatnya. Al-Tabany (2011) menyatakan bahwa:

"Pendidikan adalah pengalaman, yaitu suatu proses yang berlangsung secara terus menerus. Di sini, terdapat hubungan yang 
erat antara proses belajar, pengalaman dan berpikir. Pengalaman itu bersifat aktif dan pasif. Pengalaman yang bersifat aktif berarti berusaha, mencoba dan mengubah, sedangkan pengalaman pasif berarti menerima dan mengikuti saja. Kalau kita mengalami sesuatu, maka kita berbuat sedangkan kalau kita mengikuti sesuati kita memperoleh akibat atau hasil belajar."

Dari pendapat tersebut di atas, maka pendidikan, pembelajaran dan pengalaman pada dasarnya adalah suatu rangkaian kegiatan yang saling terintegrasi dalam pencapaian dan pembentukan individu. Ketiga komponen tersebut juga menghubungkan suatu peristiwa yang pernah dihadapi kemudian dianalisa dan disikapi sehingga menjadi peganggan untuk dapat mengatasi masalah yang sama atau persoalan-persoalan yang muncul dikemudian.

Pada titik inilah informasi literasi (information literacy) menjadi suatu kemampuan yang sangat penting untuk dimiliki oleh setiap manusia yang berakal. Informasi literasi atau keberaksaraan informasi atau juga disebut dengan melek informasi dapat menjadikan seseorang mampu utuk mengetahui kapan dan mengapa ia membutuhkan informasi, dimana menemukan informasi tersebut serta bagaimana mengevaluasi, menggunakan dan mengkomunikasikan informasi tersebut dengan cara yang beradab.

Disisi lain, hoax sebagai suatu propaganda tidak selalu harus dianggap suatu kesalahan. Terkadang propaganda diperlukan sebagi jalan menuju hidup damai sejahtera. Hamid (2012: 252) menyebutkan bahwa Ummu Kultsum menuturkan, Muhammad Rasulullah bersabda, "Tidaklah dinamakan berbohong orang yang mendamaikan sengketa diantara manusia. Ia menyampaikan kebaikan atau mengucapkan perkataan yang mendatangkan kebaikan. (HR. Bukhari dan Muslim).

Selanjutnya dalam hadits yang lain disebutkan bahwa Asma bin Yazid mengabarkan, Muhammad Rasulullah bersabda, "tidak halal bohong itu, kecuali dalam tiga hal; seorang suami berbohong kepada isterinya (atau sebaliknya) agar isterinya merasa senang; seseorang berbohong sewaktu dalam peperangan, sebab suasana perang itu penuh tipu daya; dan seseorang yang berbohong di antara dua orang Muslim yang sedang bertengkar dengan tujuan untuk mendamaikan mereka kembali." (HR. Tirmidzi).

Dari dua hadits di atas, berita propaganda memiliki rukhsoh dengan tujuan kebaikan, siasat pertempuran serta menjaga keharmonisan hidup. Namun bukan juga berarti melakukan propaganda apalagi hoax adalah sesuatu yang dibenarkan. Hal ini karena, Islam juga telah memberikanrambu-rambu terhadap umatnya dalam hal informasi, diantaranya dengan memeriksa informasi yang datang dengan teliti. Sebagaimana firman Allah sebagai berikut:

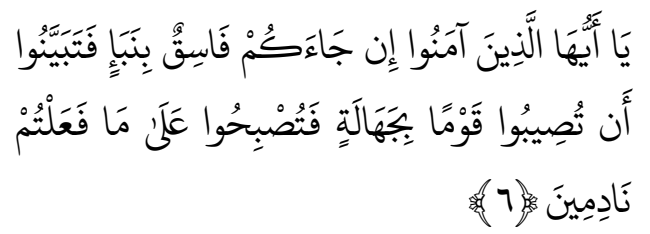

"Hai orang-orang yang beriman, jika datang kepadamu orang fasik membawa suatu berita, maka periksalah dengan teliti, agar kamu tidak menimpakan suatu musibah kepada suatu kaum tanpa mengetahui keadaannya yang menyebabkan kamu 
menyesal atas perbuatanmu itu." (QS. alHujurat [49]: 6).

Berdasarkan ayat tersebut, maka Islam sebenarnya memerintahkan kepada seluruh umatnya untuk menjauhi hoax dan bersikap tabayun dan teliti, yaitu dengan melakukan check dan recheck serta mengklarifikasi jika memperoleh informasi apalagi yang berkaitan dengan kepentingan umat. Selain itu, hoax bukanlah perkara sederhana, diperlukan kaderisasi individu-individu yang memiliki kecerdasan intelektual dan moral yang tinggi untuk menekan sekaligus mencegah terjadinya kerusakan ini.

Dari berbagai penjelasan di atas, secanggih apapun teknologi yang dipakai, tidak akan efektif apabila sejak awal seseorang memanng sudah tidak berlandaskan pada visi dan misi yang benar. Media sosial sekalipun yang dianggap canggih akan kehilangan kemampuannya selama manusianya tidak berpihak pada kebenaran. Akan tetapi beda ceritanya jika seseorang sejak awal yakin bahwa ia memihak pada kebenaran, maka media sosial menjadi alat efektif untuk menjalankan misinya.

\section{Kesimpulan}

Hoax di media sosial seperti facebook menjadi suatu fenomena yang seolah-olah telah berakar dan sulit untuk diberantas. Hoax bekerja seperti virus yang melumpuhkan sel utama yang bermanfaat bagi tubuh. Seperti halnya virus, hoax bukanlah mahluk hidup yang dapat hidup mandiri. Namun pemilihan majikan yang tepat menjadikan virus ini dapat berkembang, menyebar serta merusak sistem jaringan yang sehat. Begitu pula sebaliknya dengan warganet yang ada diantara mereka tidak mempertimbangkan suatu tindakan untuk berbagi berita yang belum tentu kebenarannya. Disini, tanpa mereka sadari sedang menyemai benih-benih prasangka yan terkadang dibubuhi oleh kebencian dan permusuhan.

Warganet mesti bijaksana dalam menyikapi penggunaan media sosial, karena tanpa adanya kebijaksanaan teknologi ini tidak dapat dipergunakan dengan baik dan hanya membuat kehancuran. Selain itu, kaderisasi individuindividu yang memiliki kecerdasan intelektual dan moral yang positif sangat dibutuhkan untuk menekan sekaligus mencegah terjadinya kerusakan akibat penyalahgunaan media sosial.[]

\section{Daftar Pustaka}

Affandi, Muhajir. 2017. Komunikasi Propaganda Suatu Pengantar. Yogyakarta: Budi Utama.

Atmadjati, Arista. 2018. Layanan Prima dalam Praktik Saat Ini. Yogyakarta: Deepublish.

Bungin, Burhan. 2018. Komunikasi Politik Pencitraan. Jakarta: Prenada Media Group.

Daymon, Christine dan Immy Holloway. 2008. Metode-metode Riset Kualitatif dalam Public Relations. terj. Cahya Wiratma. Yoyakarta: Penerbit Bentang.

Firda, Sabila J. dan Arum Faiza. 2018. Arus Metamorfosa Milenial. Kendal: Achmad Jaya Group.

Hamid, Syamsul Rijal. 2015. Buku Pintar Hadits. Jakarta: Penerbit Qiblat.

Khozin, Muhammad. 2018. Santri Milenial. Jakarta: Penerbit Bhuana Ilmu Populer. 
Musfah, Jejen. 2018. Analisis Kebijakan Pendidikan: Mengurai Krisis Karakter Bangsa. Jakarta: Kencana.

Nugraha, Muhamad Tisna. 2018. "Fundamentalisme Pendidikan Agama di Jejaring Sosial Media." Jurnal Al-Tahrir 18(1):41-62.

Pertiwi, Wahyunanda Kusuma. 2019. "Facebook Jadi Medsos Paling Digemari di Indonesia.”

Qadaruddin, Muhammad. 2016. Kepemimpinan Politik Perspektif Komunikasi. Yogyakarta: Deepublish.

Rakhmat, Nur. 2017. Dakwah Bil Koran. Bandung: Kaifa Publishing.
Sugiharto, Bintoro Agung. 2016. "Penyebar Berita Hoax di Indonesia Bisa Raup Rp. 700 Jutaan."

al-Tabany, Trianto Ibnu Badar. 2011. Desain Pengembangan Pembelajaran Tematik bagi Anak Usia Dini TK/RA dan Anak Kelas Awal SD/MI. ed. J. Alfin. Jakarta: Kencana.

Umar, Husein. 2003. Metode Riset Bisnis. Jakarta: PT. Gramedia Pustaka Utama. 